Željko Jokićc ${ }^{\star}$, Boris Delibašić ${ }^{2}$, Aca Ranđelović

${ }^{1}$ Military Academy of the University of Defense in Belgrade, Serbia

${ }^{2}$ University of Belgrade, Faculty of Organizational Sciences, Serbia

\title{
Selection of Rifle Caliber in Rearming Process of the Serbian Army
}

DOI: 10.7595/management.fon.2021.0011

Abstract:

Research Question: This paper recommends the method for selecting the optimal ammunition caliber for the automatic rifle that will be used to equip Serbian Army units. Motivation/idea: The selection of adequate caliber does not only represent a challenge for the decision-makers in the military, but also provides information to the industry to adjust to given requests. In the current conditions, the purpose-built industry of the Republic of Serbia is faced with two key tasks that are completely correlated: meeting the needs of the Serbian Army for quality ammunition and being competitive on the market. Accordingly, the purpose of this paper is to develop a qualitative model based on the DEX method and DEXi software applied in the selection of caliber ammunition for automatic rifles for the needs of members of the Serbian Army. This paper connects for the first time the qualitative DEX method with a product of this industry. Data / Tools: In order to meet the requirements of the multi-criteria decision-making, we developed the DEX model to be used to solve the problem of making decisions about the selection of optimal caliber for rearming the Serbian Army, as well as its cost-effectiveness. The alternatives are calibers for automatic rifles $7.62 \mathrm{~mm}$ and $5.56 \mathrm{~mm}$ that are currently in use in the Serbian Army, as well as the new $6.5 \mathrm{~mm}$ caliber which has been announced by the expert authorities. We defined the selection of criteria functions from technical and logistic standpoints. Using the DEX method and DEXi software enables us to obtain independent recommendations by applying different criteria. Findings: Results of this research show that the caliber is a very important component when it comes to army's armament. At the same time, this question poses a challenge for the sustainable development of the weapons industry. As the optimal caliber, among the offered, after processing the input data in the DEXi software, the authors propose a caliber of $5.56 \mathrm{~mm}$. This caliber dominates in most criteria and as such, it represents the best choice. Contribution: This paper contributes to the creation of sustainable development policies on the national and regional levels and it helps the key decision-makers in the military make decisions. Results of such and similar research, and the fact that the international market has a growing need for ammunition of this caliber should be guidelines for the domestic weapons industry for future development and investment.

Keywords: multicriteria decision-making, DEX method, DEXi software, caliber, ammunition, cost-effectiveness.

JEL Classification: D81

\section{Introduction}

Despite claims from certain theorists that the twenty-first century is the century of modern warfare and that classic wars are a thing of the past we are witnesses that these claims are incorrect. Every day, across the world, there are dozens of armed conflicts of greater or smaller intensity. Putting aside all the destructive characteristics of the armed conflicts we cannot neglect their development potential, nor their significant economic benefits. The industry that in theory makes the most profit from these conflicts is the military industry. That is, as cruel as it may sound, armed conflicts are the only realistic test where we can evaluate products of the weapons industry.

As we will not see the end of the use of conventional weapons soon, the development of the existing weapons as well as creating new ones will not stop. In parallel with the development of weapons, different types of ammunition are developed that will be used by those weapons. As rifle ammunition does not con- 
tain an explosive charge and has effect on the target only by using kinetic energy, it was necessary to develop a lighter bullet with a higher initial velocity and better in-flight stability (Bogdanov, 2015).

There is a large number of types of ammunition that are sorted out by caliber. The two most used calibers are the $7.62 \mathrm{~mm}$ and $5.56 \mathrm{~mm}$. The Yugoslav People's Army started using the eastern version of caliber $7.62 \times 39 \mathrm{~mm}$, which the Serbian Army kept using, while the western (NATO) version is $5.56 \times 51 \mathrm{~mm}$. Since 2008, the Serbian Army has used the $5.56 \mathrm{~mm}$ caliber along with $7.62 \mathrm{~mm}$. Lately, we have had announcements suggesting the introduction of the new caliber, $6.5 \mathrm{~mm}$ Grendel.

The question of ammunition caliber selection depends mostly on internal manufacturing capacities that can both meet the needs of the Serbian Army and possess export potential. With that said, one should take into account that economic criteria most often give priority to political criteria, through appropriate institutional support. Because of this, along with the development of manufacturing capacities, we take into consideration international markets where it is possible to sell.

By using the expert modeling DECISION EXPERT (DEX) method, this paper compares caliber $6.5 \mathrm{~mm}$ to calibers $5.56 \mathrm{~mm}$ and $7.62 \mathrm{~mm}$, that are already in use, in order to include it in the process of rearming the Serbian Army while acknowledging economic potential. Calibers are compared through two types of characteristics: technical (mass of the bullet, initial velocity, and kinetic energy) and logistical (number of rifles, magazine capacity, and the price of a bullet), that are according to the opinions of the experts decisive in the selection process. Despite the unwritten rule that the price of rearming cannot be an obstacle (Eloranta, 2005), this does not hold for transitioning countries such as the Republic of Serbia. The logistic characteristic, the price of the bullet, due to economic circumstances, has the same importance as technical characteristics (Mucibabic, 2014).

Cupic and Suknovic (2010) write about decision-making in their work. Jokic et al. (2019) write about the problem of selection of caliber for the Serbian Army units. The method of multicriteria decision making is iterative compromise ranking (VIKOR) that proved to be very effective when it comes to solving this and similar problems.

The above-mentioned paper shows that going with the $5.56 \mathrm{~mm}$ is currently the best choice because it dominates in most criteria. By accepting the recommended solution, the decision-maker avoids subjectivity and strengthens his position with arguments based on results from the VIKOR method (Jokic et al., 2019).

As we use the DEX method in this paper, in the end, we will compare the results of one quantitative and one qualitative decision-making method.

Due to the very nature of the problem, it is difficult to find a similar paper that connects the selection of ammunition and multi-criteria decision-making using DEXi software, which certainly does not mean that products of the domestic industry are not a subject of multi-criteria analysis. On the contrary, considering that the decisions about rearming from the domestic industry are made on the strategic level, the need to use tools that help decision-makers is more emphasized.

As already mentioned, Jokic et al. (2019) conducted a similar study using the VIKOR method. Sanchez, Serna \& Dolon (2015) used multi-criteria decision-making and fuzzy logic to make the selection of the best training jet for the Spanish Military Academy while Petrovic \& Kankaras (2018) used DEMATEL-AHP methods for the selection of the best jet for protection of the Serbian airspace. The same authors apply the Fuzzy - AHP approach in evaluating the criteria for selecting a missile system for anti-aircraft operations (Petrovic et al., 2018). Methods of the multi-criteria decision-making for the selection of the best jet were also used by Wibowo et al. (2016). Bozanic et al. (2020) use a hybrid LBWA - IR-MAIRCA model of multi-criteria decision-making for the selection of weapons. Radovanovic et al. (2020) apply the fuzzy AHP-VIKOR method to select the best method for rectifying sniper rifles.

In addition to the choice of weapons system, multi-criteria analysis is also applicable during the preparation of military operations. Bojanic et al. (2018) used multi-criteria decision-making when planning the use of an anti-tank missile battery in a defensive operation. Similarly, Petrovic \& Kankaras (2020) conducted a case study of the selection and evaluation of criteria for determining the position of air traffic control radar. Bozanic et al. (2016) applied the MABAC method in support of decision-making on the use of force in a defensive operation. al. (2014) use multi-criteria decision-making to select a location for the distribution of humanitarian aid. 


\section{Development of Rifle Ammunition}

The development of weapons was followed by the development of ammunition that was used by them. We take the $7.92 \times 33 \mathrm{~mm}$ (for the assault rifle StG 44) and the bullet $7.62 \times 39 \mathrm{~mm}$ (for the automatic rifle AK-47) as the first successful cases. This family of ammunition had great mass, that directly affected the range and the mass of equipment (Bogdanov, 2015). The current trends, when it comes to the development of rifle ammunition, that is, improvement tactical and technical characteristics, are going in several directions: reducing caliber size, increasing slenderness, and increasing the initial velocity of the bullet (Bogdanov, 2015).

As a result of significant losses of the US armed forces during the war in Vietnam, it was necessary to develop a bullet that would have higher initial velocity and kinetic energy on the target (Woodford, 2019). This was achieved by introducing ammunition with a $5.56 \mathrm{~mm}$ caliber. The first version was 5.56x45 mm M193 and demonstrated certain flaws that were removed with the $5.56 \times 45 \mathrm{~mm} \mathrm{SS} 109$ bullet. This bullet became the standard bullet in the NATO member countries.

At the beginning of the twenty-first century, a new bullet was introduced, the $6.5 \mathrm{~mm}$ Grendel caliber, which offered an opportunity to meet different tactical and technical requests and be the middle ground for 5.56 $\mathrm{mm}$ и $7.62 \mathrm{~mm}$ calibers. The $6.5 \times 39 \mathrm{~mm}$ Grendel caliber bullet is still mostly used by hunters.

Following the decision to join the "Partnership for peace", in order to be compatible with the members of NATO, decision-makers in Serbia decided to rearm the army with the new automatic rifle, that is made in Serbia and uses the $5.56 \times 45 \mathrm{~mm}$ caliber - the M21 rifle. During 2008, the army received the first delivery of about 5000 pieces of these rifles. As rearming an army is a serious and expensive process, some Serbian Army units still use older M70 rifles.

The Serbian ammunition factory „Prvi partizan” from Uzice was awarded the contract for manufacturing the $6.5 \times 39 \mathrm{~mm}$ Grendel bullet that is suitable for both hunting and military rifles.

A new modular automatic rifle that uses the $7.62 \times 39 \mathrm{~mm}$ caliber and $6.5 \times 39 \mathrm{~mm}$ M17 Grendel caliber was developed as a product of cooperation between two domestic factories "Zastava oruzje” from Kragujevac and „Prvi partizan” from Uzice (Bogdanovic, 2018).

The Serbian Army uses the $5.56 \times 45 \mathrm{~mm}$ caliber M21 rifle as well as the $7.62 \times 39 \mathrm{~mm}$ caliber M70 rifle. Following the successful testing process of the modular $6.5 \times 39 \mathrm{~mm}$ Grendel caliber - M17 rifle, the need to switch to this caliber is mentioned more often in the expert community. However, considering the price of the new bullet, the replacement of the rifles in the operational usage in total and development of the new rifle, the question of whether the Serbian Armed Forces really need this switch poses itself due to current economic situation, especially when it is taken into account that no other army in the world has the abovementioned caliber in the operational usage. By using the qualitative model of multi-criteria decision-making DEX and DEXi software will be attempted to answer that question.

\section{Decision Expert (DEX) Method}

Modern managers less often rely solely on intuition when making decisions; instead, they use various methods and techniques for those purposes. There has been a large number of methods that were developed in order to help us when solving different managerial problems. A majority of those methods are quantitative; however, it is not always possible to demonstrate all elements of the problem. In order to avoid problems it is possible to replace quantitative methods with qualitative ones.

The development of qualitative models with multiple attributes is based on qualitative multi-attribute modelling. Models with multiple attributes (or multiple criteria) are tools used in the analysis of decisions for evaluation and selection of alternatives (Bohanec \& Delibasic, 2015). These models are most often created as a result of cooperation between decision-makers, experts, and analysts.

In this paper, we used the Expert Modeling DEX model (Bohanec et al., 2013) developed in 1979 (Bohanec, 2008). It has been continuously developed and implemented in a wide spectrum of computer programmes. The DEX models and methodologies are in use even today in numerous aspects of society: sports, human resources, medicine, traffic studies, banking, risk assessment, etc.

DEX is an interactive computer programme for the development of quantitative models with multiple attributes and options assessment (Bohanec \& Rajkovic, 1990) aimed at supporting decision-makers in complex 
decision-making problems. Unlike other decision-making systems with multiple attributes, DEX uses qualitative (symbolic) attributes instead of quantitative (numeric) ones. Also, it works by the "if-then" rules of decision making, instead of weighted sums.

DEX models are based on the following principles (Bohanec et al., 2013):

- The model consists of hierarchical decomposition attributes in such a way that attributes at a higher level depend on those at a lower level.

- The attributes have scales expressed in words (i.e. "good", "bad", etc.) whose order of elements is lowest to highest values.

- For each "parent" attribute (attribute of a higher level) a table of elementary rules needs to be defined which is used to map values from lower to a higher hierarchical level. In those tables, one needs to define all possible combinations of "parent" attributes compared to "children" - attributes (attributes of a lower level).

- Following defined scales and relationships between attributes, we check for consistency in rules and prevent the development of rules which would violate this principle.

- The principle that states that "the customer is always right" is followed, even when some of the rules are inconsistent, although one should always lean towards a set of rules that is as consistent as possible.

The first principle - hierarchical decomposition of attributes is very intuitive and practical because it enables the problem to be decomposed into smaller pieces and be solved easier. Defining scales of attribute values by the user enables us to adjust to the observed problem. If it is necessary to digress from the previous rule, the model offers this possibility because it is assumed that the expert (decision-maker) is always right.

The DEX method consists of five steps:

Step 1: DEX model structuring.

Structuring of the DEX model can be conducted in two ways: Top-down approach and Bottom-up approach. In this paper, we used the first way. Structuring is done within the Model tab by selecting the target attribute, and then breaking down that attribute into lower-order attributes. Target attributes are displayed as rectangles and data attributes as arrows.

Step 2: Defining qualitative scales of attribute values

For each of the attributes in the model, a scale of values must be defined. While defining the scale, it is necessary to pay attention to whether the attribute, by its meaning, is of the maximization or minimization type because the order of elements will be different. Regardless of the team of extremization that arises from the importance of the attribute, the scale is oriented to be increasing. Defining the scale of attribute values is done within the Scale option.

\section{Step 3: Defining decision rules}

For each combination of input children-attributes, it is necessary to enter a value for the parent-attribute. The Use scale orders option enables us to check for consistency, and the Use weights option enables us to fill in the missing rules based on regressive weights of attributes. This step depends entirely on the knowledge of experts.

\section{Step 4: Enter alternatives}

After defining all the parameters, the model should be presented with alternatives from which to choose the best. Only the values of the elementary attributes are entered in the Options tab.

Step 5: Evaluate alternatives and analyze the results

As with other methods of multi-criteria decision-making, the DEX method also needs an evaluation of the stability of the solution. For stability analysis, DEXi offers three options: analysis $+/-1$ (Plus-minus-1 analysis), Selective explanation, and Compare options.

Plus-minus-1 analysis enables us to check how an independent change of any attribute, for one value up or one value down, affects the overall change of values of attributes on the higher level (attribute-parent). An empty field implies that a change in the value of an attribute at a lower level, does not affect the "older" attributes, while "[" or "]" imply that it is not possible to conduct changes at a lower level.

A selective explanation emphasizes special advantages and shortcomings of the selected option. The method discovers and shows only the connected subtrees of attributes for which the option was evaluated as especially good or bad. 
Comparing alternatives enables us to simply choose which alternatives we want to compare. Based on the comparison we get a report which is similar to a regular report about results of evaluation but with emphasized differences between options. Alternatives comparison can be done with charts by using the Charts tab where it is possible to select several types of charts. If we choose only one attribute, we will get the bar-chart, and if we choose two attributes, we will get the scatter- plot. If we choose three or more attributes, we will get the radar-chart. Charts are of triangular, rectangular, or trapezoidal shape, depending on the number of sub criteria that we choose.

\section{Application of DEXi Software in Caliber Selection}

The DEX models are made in DEXi software. Models with multiple attributes form a tree structure (Erdogan et al., 2018). The upper attribute in such models represents the total problem, while attributes below it represent subproblems that are smaller and less complex. DEXi software represents the system for support in decision-making that has two purposes:

- To help the analyst develop a model based on expert experiences, and

- To apply developed models in the process of making the decision.

As stated above, DEXi software is used in numerous aspects of society. Karleusa et al. (2018) used DEXi software for prioritizing the execution of plans for irrigation in the river Orljava basin in Pozesko-slavonska municipality in Croatia. Saracoglu (2016) also used DEXi software when making a selection of possibilities for investment in hydro-energy in Turkey. Maksimovic et al. (2017), using the DEX method, selected an adequate choice sort of fruit for starting production while Rozman et al. (2017) used the DEX method for choosing the best sort of plum. Pavlovic et al. (2011) developed a DEX-HOP model for the preliminary assessment of hop hybrids. Craheix et al. (2015) based on feedback from decision support systems DEXi design models for agricultural sustainability. Kontic et al. (2006) use the DEX method to search for the best location for the disposal of radioactive waste from the Krško Nuclear Power Plant. The DEX method has been used by some authors to make business decisions (Zupanic, 2017). Hiti (2019) uses theDEX method for restructuring of farms in Primorsko-notranijska region.

The multidisciplinarity of software is reflected in the fact that it can also be used in risk assessment (Radovanovic et al., 2019; Delibasic et al., 2020). Since the DEX method is similar to the AHP method, Kosljar \& Rajkovic (2014) used these methods together in the decision-making process.

\section{Model structure}

In an environment that is increasingly dynamic and prone to changes, the crucial question is how to make the right decision. Decision making is a choice among multiple possible alternatives (alternative solutions) tor the observed problem (Jokic et al., 2019). In order to make the decision completely and qualitatively, it is necessary to conduct it through the following phases: identifying the problem, generating alternatives and criteria of optimality, evaluation, and selection, implementation, and control (Nikolic \& Borovic, 1996).

The model for an optimal rifle caliber selection consists of eight hierarchically structured attributes shown in the attribute tree (Figure 1). Besides the main criterion, „caliber selection“, the model is based on two criteria, technical and logistical characteristics, and they are divided into sub-attributes. Attributes and sub-attributes are listed based on studies of the theory of shooting from infantry weapons and experts' opinions.

Attributes, technical and logistical characteristics, are divided into elementary attributes according to the following:

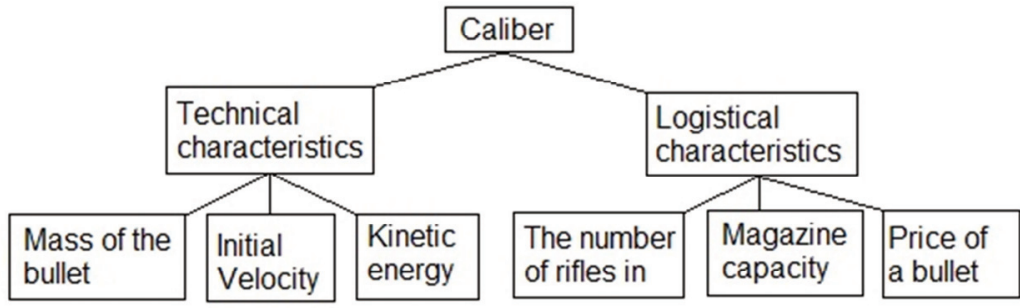

Figure 1: Attribute tree 
The final result of the modelling phase of the selection of the optimal rifle caliber for the needs of the Serbian Army described in Step 1, is shown in Figure 2.

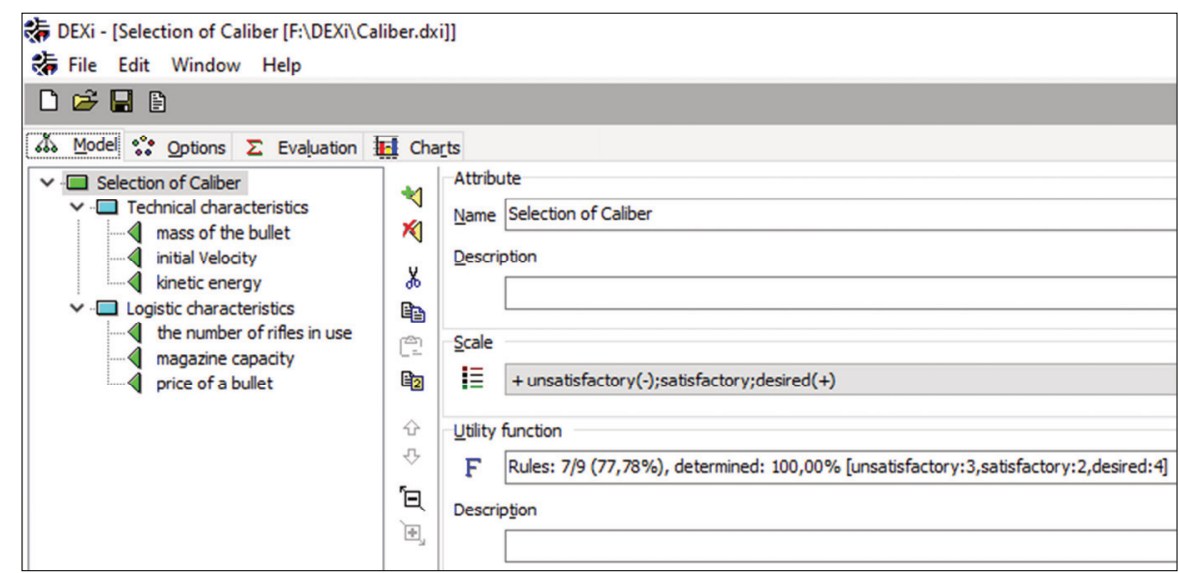

Figure 2: Model Tab

\section{- Values Scale and decision-making rules}

The scale for model evaluation for all criteria and sub-criteria consists of three levels of values as shown in table 1.

Table 1: Values Scale

\begin{tabular}{|c|c|c|}
\hline \multicolumn{2}{|c|}{$\begin{array}{c}\text { Attributes and Sub } \\
\text { Attributes }\end{array}$} & Values Scales \\
\hline & Caliber & unsatisfactory,satisfactory, desired \\
\hline 1 & $\begin{array}{c}\text { Technical } \\
\text { characteristics }\end{array}$ & poor, satisfactory, good \\
\hline 1.1. & Mass of the bullet & small, optimal,large \\
\hline 1.2. & Initial velocity & small, average, large \\
\hline 1.3. & Kinetic energy & small, average, large \\
\hline 2 & $\begin{array}{c}\text { Logistical } \\
\text { characteristics }\end{array}$ & poor, satisfactory,good \\
\hline 2.1. & $\begin{array}{c}\text { The number of } \\
\text { rifles in use }\end{array}$ & minimal, required, sufficient \\
\hline 2.2. & Magazine capacity & small,standard, large \\
\hline 2.3. & Price of bullet & high, optimal, low \\
\hline
\end{tabular}

Defining the attribute value scale, described in Step 2, is shown in Figure 3.

\begin{tabular}{|l|l|}
\hline increasing Scale Selection of Caliber & \\
\hline \hline Value & \\
$\diamond$ unsatisfactory & \\
$\diamond$ satisfactory & \\
$\uplus$ desired & \\
\hline
\end{tabular}

Figure 3: Defining values scale

After defining the value scale, the decision rules are defined. The rules were defined based on expert interviews, as described in Step 3. Applied rules are shown in Figure 4. 


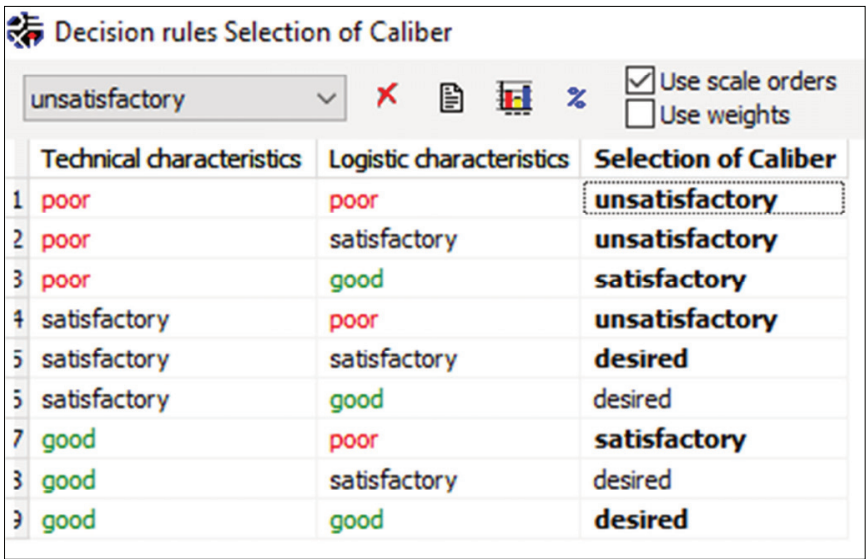

Figure 4: Rules of decision-making

\section{- Alternatives entry}

The shown sub-attributes, as technical and logistical characteristics, have their exact quantitative values obtained based on measurements at testing centers, evaluations of authors based on the Serbian Army numbers, technical data about weapons systems, and available data provided by manufacturers. For the needs of the model, the quantitative values were translated into qualitative descriptive, as it is shown it Table 2.

Table 2: Linguistic descriptors

\begin{tabular}{|c|c|c|c|}
\hline \multicolumn{2}{|c|}{ Sub Attributes } & Linguistic values & Numerical values \\
\hline \multirow{2}{*}{1.1.} & Mass of the bullet (g) & small & $<13$ \\
& & optimal & $13-17$ \\
& & large & $17<$ \\
\hline \multirow{2}{*}{1.2.} & Initial velocity (m/s) & small & $<700$ \\
& & average & $700-800$ \\
& Kinetic energy (J) & large & $800<$ \\
\hline \multirow{2}{*}{1.3.} & & small & $<700$ \\
& & average & $700-900$ \\
& & large & $900<$ \\
\hline \multirow{2}{*}{2.1.} & The number of rifles in use (pcs.) & minimal & $<10000$ \\
& & required & $10000-50000$ \\
\hline \multirow{2}{*}{2.2.} & Magazine capacity (pcs.) & sufficient & $50000<$ \\
& & small & 20 \\
& & standard & 30 \\
\multirow{2}{*}{2.3.} & Price of bullet (din. RS) & large & $30<$ \\
& & high & $<30$ \\
& & optimal & $30-50$ \\
& & low & $50<$ \\
\hline
\end{tabular}

The entered alternatives, as described in step 4, are shown in Figure 5.

\begin{tabular}{|c|c|c|c|}
\hline \multicolumn{4}{|c|}{ 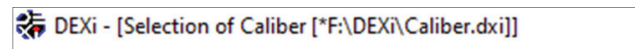 } \\
\hline \multicolumn{4}{|l|}{ 可早自 } \\
\hline \multicolumn{4}{|c|}{ Model $\because:$ Options $\Sigma$ Evaluation 些 Charts } \\
\hline $5.56 \mathrm{~mm}$ & $+x$ & $\Leftrightarrow \Rightarrow$ & 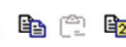 \\
\hline Option & $5.56 \mathrm{~mm}$ & $6.5 \mathrm{~mm}$ & $7.62 \mathrm{~mm}$ \\
\hline mass of the bullet & small & optimal & large \\
\hline initial Velocity & large & large & average \\
\hline kinetic energy & average & large & small \\
\hline the number of rifles in use & minimal & minimal & sufficient \\
\hline magazine capacity & standard & small & standard \\
\hline price of a bullet & optimal & high & low \\
\hline
\end{tabular}

Figure 5: Alternatives Entry 


\section{- Evaluation of alternatives and analysis of results}

The output results of the applied model are shown in Figure 6.

\begin{tabular}{|c|c|c|c|}
\hline $\begin{array}{l}\text { 蹄 DEXi - [Selection of Caliber } \\
\text { 捗 File Edit Analysis Win }\end{array}$ & 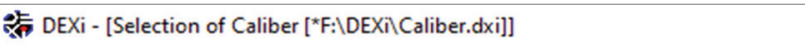 & & \\
\hline \multicolumn{4}{|c|}{ 口光回曾 } \\
\hline \multicolumn{4}{|c|}{$\therefore$ Model $\because$ Options $\Sigma$ Evaluation 票 Charts } \\
\hline$\checkmark$ 䟚 & 趼 绝 1 汗 $\Delta$ & $n \infty$ & \\
\hline Option & $5.56 \mathrm{~mm}$ & $6.5 \mathrm{~mm}$ & $7.62 \mathrm{~mm}$ \\
\hline Selection of Caliber & desired & satisfactory & satisfactory \\
\hline .. Technical characteristics & satisfactory;good & good & poor \\
\hline ... mass of the bullet & small & optimal & large \\
\hline ... initial Velocity & large & large & average \\
\hline .... kinetic energy & average & large & small \\
\hline .. Logistic characteristics & satisfactory & poor & good \\
\hline ...the number of rifles in use & E minimal & minimal & sufficient \\
\hline ... magazine capacity & standard & small & standard \\
\hline ...p price of a bullet & optimal & high & low \\
\hline
\end{tabular}

Figure 6: Evaluation of alternatives

Following the evaluation of entered alternatives, one can see that output values for calibers are $5.56 \mathrm{~mm}-$ "desired", $6.5 \mathrm{~mm}$ - "satisfactory" и $7.62 \mathrm{~mm}$ - "satisfactory", which means that caliber $5.56 \mathrm{~mm}$ has the fewest bad characteristics. Based on the above, it can be concluded that $5.56 \mathrm{~mm}$ is proposed as the most optimal caliber.

The Plus-minus-1 analysis

The results of the $+/-1$ analysis, for the proposed $5.56 \mathrm{~mm}$ caliber, are shown in Figure 7 .

\begin{tabular}{|c|c|c|}
\hline DEXi & \multicolumn{2}{|c|}{ Caliber.dxi 15.02.2021. } \\
\hline Plus-Minus- 1 analysis & & \\
\hline Attribute & -1 & $5.56 \mathrm{~mm}+1$ \\
\hline $\begin{array}{l}\text { Selection of Caliber } \\
\begin{array}{|l}\text { - mass of the bullet } \\
\text {-initial Velocity } \\
\text { - kinetic energy } \\
\text {-the number of rifles in use } \\
\text {-magazine capacity } \\
\text { - price of a bullet }\end{array}\end{array}$ & $\begin{array}{l}\text { unsatisfactory } \\
\text { unsatisfactory; } \\
\text { unsatisfactory; }\end{array}$ & $\begin{array}{l}\text { desired } \\
\text { [ small } \\
\text { large ] } \\
\text { average } \\
\text { [ minimal } \\
\text { y standard } \\
\text { y optimal }\end{array}$ \\
\hline
\end{tabular}

Figure 7: „Plus-minus-1 analysis“ of $5.56 \mathrm{~mm}$ caliber

Figure 8 shows that for $5.56 \mathrm{~mm}$ caliber, a change for one value up or one value down does not affect the main attribute "selection of caliber" which means that even after Plus-minus-1 analysis, caliber $5.56 \mathrm{~mm}$ remains "desired", that is, it keeps stability.

\section{Selective explanation}

Figure 8 shows that the first ranked caliber $5.56 \mathrm{~mm}$ has two weak and two strong characteristics: the weak ones are bullet mass and the number of rifles in use, while the strong ones are technical characteristics, especially the initial velocity. 


\begin{tabular}{|c|c|}
\hline DEXi & Caliber.dxi \\
\hline \multicolumn{2}{|l|}{ Weak points } \\
\hline Attribute & $5.56 \mathrm{~mm}$ \\
\hline $\mid$ - mass of the bullet & small \\
\hline \multicolumn{2}{|c|}{$\vdash$ the number of rifles in use minimal } \\
\hline \multicolumn{2}{|l|}{ Strong points } \\
\hline Attribute & $5.56 \mathrm{~mm}$ \\
\hline $\begin{array}{l}\text { Selection of Caliber } \\
\text { - Technical characteristics } \\
\text {-initial Velocity }\end{array}$ & $\begin{array}{l}\text { desired } \\
\text { satisfactory; good } \\
\text { large }\end{array}$ \\
\hline
\end{tabular}

Figure 8: Analysis of selective explanation

Alternatives comparison

Figure 9 shows the marked differences between the alternatives.

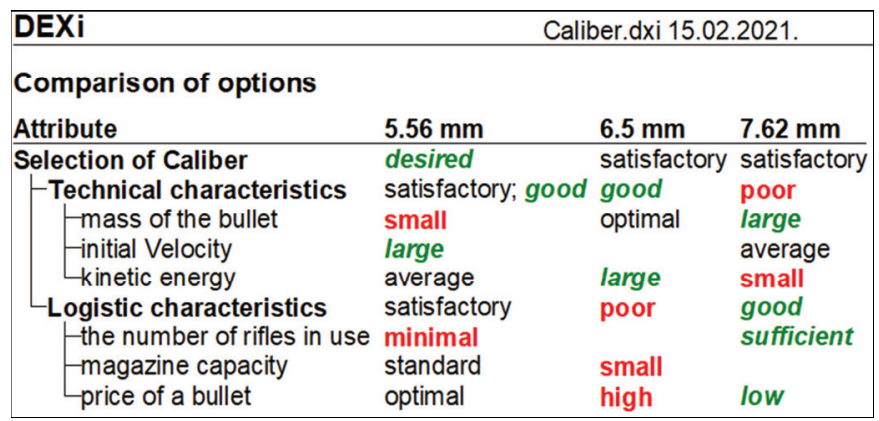

Figure 9: Alternatives comparison

The graph in Figure 10 shows the evaluation results according to one dimension of the evaluation. In this case, it is the basic attribute, "caliber selection".

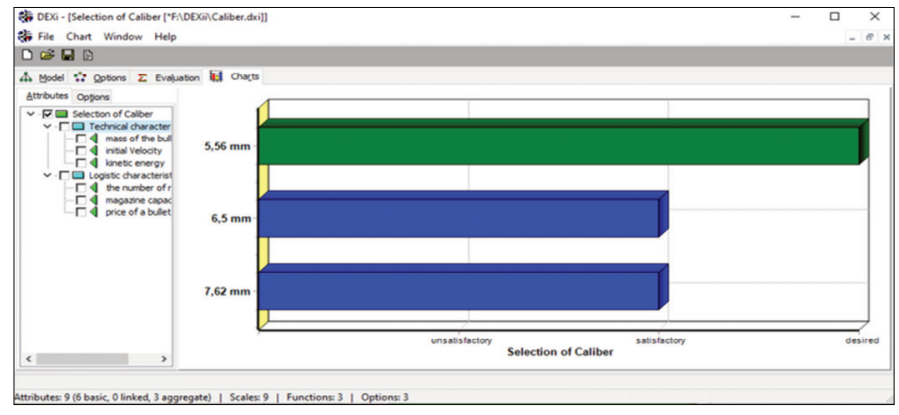

Figure 10: Chart of Alternatives comparison (bar-chart)

Figure 11 shows a triangular chart, evaluation of the main attribute: „caliber selection“ and its sub-attributes "technical and logistical characteristics" that are observed for the dominant caliber.

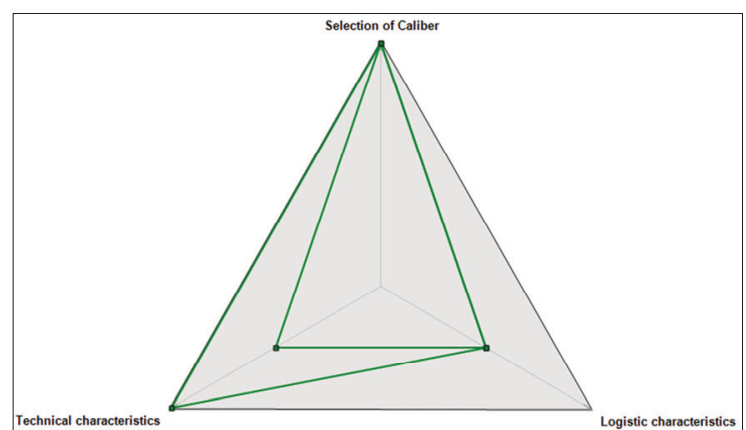

Figure 11: Evaluation of main criteria for caliber $5.56 \mathrm{~mm}$ (Radar-chart) 
Triangle vertices represent the best values of the observed attributes and sub attributes. As values of sub attributes get lower, it is shown on the chart by approaching the center of the triangle and the worst criterion is in the center. Figure 11 shows that for caliber $5.56 \mathrm{~mm}$ the "technical characteristics" attribute has a higher value than "logistical characteristics" but not as high as in the other two calibers. While $6.5 \mathrm{~mm}$ and $7.62 \mathrm{~mm}$ calibers had "technical and logistical characteristics" evaluated as "good" or "bad", $5.56 \mathrm{~mm}$ caliber results in "satisfactory", with tendencies for "good" for "technical characteristics" attribute, and therefore, the $5.56 \mathrm{~mm}$ caliber was recommended as the "desired" one.

Triangle vertices represent the best values of the observed attributes and sub-attributes. As values of subattributes get lower, it is shown on the chart by approaching the center of the triangle and the worst criterion is in the center. Figure 11 shows that for caliber $5.56 \mathrm{~mm}$ the "technical characteristics" attribute has a higher value than "logistical characteristics" but not as high as in the other two calibers, and therefore, the $5.56 \mathrm{~mm}$ caliber was recommended as the "desired" one.

\section{Conclusion}

The decision to introduce a new weapons system is not made ad hoc, nor is it the decision made by one man, regardless of the expertise he might possess. Decisions of this kind, especially when it comes to changing the caliber as the technical and unit price as the logistical standpoint, is the result of thorough expert research and long-term planning of technical development as well as finances.

By using qualitative and quantitative methods when choosing the optimal caliber that meets the needs of the Serbian Army and also meets the budget requirements, we decrease the risks of making the wrong decision from both the technical and the financial standpoints. The results of previous research, mentioned in the introductory part, obtained through VIKOR methods are very similar, almost identical, just like the results obtained by using the Decision Expert (DEX) method by using the DEXi software. In both cases, the $5.56 \mathrm{~mm}$ caliber is the best solution. This caliber highly satisfies the majority of criteria and, as such, it is the best choice.

Another fact that supports these findings is that there are two additional production lines in use at a domestic factory „Prvi Partizan" from Uzice introduced in 2015 that increased the existing capacities by $30 \%$ and thus enable timely deliveries of required $5.56 \mathrm{~mm}$ ammunition.

In this paper, we presented one approach based on the DEX method using DEXi software. The software proved to be relatively simple to use and successful when solving problems and reducing unpredictability and uncertainty when making decisions, thus enabling us to make a more objective and correct selection among offered alternatives.

Future research in this area needs to focus on applying hybrid models while using qualitative and quantitative methods of multi-criteria decision-making in order to reduce shortcomings of the applied method and to develop a more realistic and efficient model of decision making.

\section{REFERNCES}

[1] Bogdanov, J. (2015). Poznavanje ubojnih sredstava - prvi deo, Udžbenik, Medija centar Odbrana, Beograd.

[2] Bogdanovic, B. (2018). Srpska puška 17 Grendel - prvi uspešno razvijeni „trol” u svetu, Retrieved from (accessed 02.03.2020.).

[3] Bojanic, D., Kovac, M., Bojanic, M. \& Ristic, V. (2018). Multi-criteria decision-making in A defensive operation of the guided anti-tank missile battery: An example of the hybrid model fuzzy AHP - MABAC, Decision Making: Applications in Management and Engineering, 1(1), 51-66.DOI:10.31181/dmame180101

[4] Bohanec, . (2008). DEXi: Program for Multi-Attribute Decision Making Usual's Manual, Institut „Jožef Stefan“, Ljubljana.

[5] Bohanec, M. \& Delibasic, B. (2015). Data-Mining and Expert Models for Predicting Injury Risk in Ski Resorts, Research Gate. Retrieved from www.researchgate.net/publication/277131879 (accessed 19.12.2019).

[6] Bohanec, M., Znidarsic, M., Rajkovic, V., Bratko, I. \& Zupan, B. (2013). DEX methodology: three decades of qualitative multi-attribute modelling, Informatica 37(1), 49-54. Retrieved from www.informatica.si/index.php/informatica/pages/view/cfp (accessed 19.12.2019).

[7] Bohanec, M. \& Rajkovic, V. (1990). DEX: An Expert System Shell for Multi-Attribute Decision Making, Research Gate. Retrieved from https://www.researchgate.net/publication/284679050 (accessed 01.12.2019). 
[8] Bozanic, D. I., Pamucar, D. S., \& Karovic, S. M. (2016). Primene metode MABAC u podršci odlučivanju upotrebe snaga u odbrambenoj operaciji. Tehnika, 71(1), 129-136.

[9] Bozanic, D., Randjelovic, A., Radovanovic, M. \& Tesic, D. (2020). A hybrid LBWA - IR-MAIRCA multi-criteria decision-making model for determination of constructive elements of weapons, Facta Universitatis Series: Mechanical Engineering, 18(3), 399-418. DOI:10.22190/FUME200528033B

[10] Craheix, D., Bergez, J-E., Angevin, F., Bockstaller, C., Bohanec, M., et al. (2015). Guidelines to design models assessing agricultural sustainability, based upon feedbacks from the DEXi decision support system. Agronomy for Sustainable Development, Springer Verlag/EDP Sciences/INRA, 35(4), 14311447. DOI:10.1007/s13593-015-0315-0.

[11] Cupic, M. \& Suknovic, M. (2010). Odlučivanje. Beograd: Fakultet organizacionih nauka.

[12] Delibasic, B., Makajic-Nikolic, D., Cirovic, M., Petrovic, N., \& Suknovic, M. (2020). A ski injury risk assessment model for ski resorts. Journal of Risk Research, 23(12), 1590-1602. DOI: $10.1177 / 1754337117728600$

[13] Eloranta, J. (2005). Military Spending Patterns in History. EH.Net Encyclopedia, edited by Robert Whaples. September 16, 2005. Retrieved from http://eh.net/encyclopedia/military-spending-patterns-inhistory/ (accessed 25.08.2020)

[14] Erdogan, G., Refsdal A., Nygard B., Ole-Petter, R. \& Bernt-Kvam, R. (2018). Risk-Based Decision Support Model for Offshore Installations, Business Systems Research: International journal of the Society for Advancing Innovation and Research in Economy, 9(2), 55-68. DOI: 10.2478/bsrj-2018-0019

[15] Hiti, A. (2019). Določanje potenciala kmetije s pomočjo odločitvenega modela DEX. (Doctoral dissertation, Univerza $\vee$ Ljubljani, Biotehniška fakulteta).Retrieved from https://repozitorij.uni-lj.si/lzpisGradiva. php?lang=slv\&id=111554.

[16] Jokic Z., Delibasic B. \& Komljenovic S., (2019). Implementation of the VIKOR method when selecting the caliber for automatic rifles for operational use in the SAF units, Vojno delo, 71(6), 200-221.

[17] Sanchez-Lozano, J.M., Serna, J.,\& Dolon-Payan, A. (2015). Evaluating military training aircrafts through the combination of multi-criteria decision making processes with fuzzy logic. A case study in the Spanish Air Force Academy, , , 58-65. DOI: 10.1016/j.ast.2014.12.028

[18] Karleusa, B., Hajdinger, A. \& Tadic, L. (2018). Use of Multicriteria Analysis Method DEXi to Define Priorities in Implementation of Irrigation Plans, Proceedings, 2(11), 663 DOI: 10.3390/proceedings2110663.

[19] Kontic, B., Bohanec, M. \& Urbančič, T., (2006). An Experiment in Participative Environmental Decision Making. Environmentalist, 26, 5-15. DOI: 10.1007/s10669-006-5353-3.

[20] Kosljar, T., \& Rajkovic, V. (2014). Primerjalna uporaba metod DEX in AHP v procesu odločanja. Uporabna informatika, 3(22), 147-151. Retrieved from http://www.dlib.si/details/URN:NBN:SI:doc-YYYENX1C

[21] Maksimovic, A., Grgic, Z., \& Cejvanovic, F. (2017). Multi-Attribute Analysis of Orchard According to the Integrated Production Concept. Economics of Agriculture, 64(1), 69-79. DOI:10.5937/ekoPolj1701069M

[22] Mucibabic S. (2014). Predlog modela cene koštanja vojne operacije, Vojno delo, DOI: 10.5937/vojdelo1404020M.

[23] Nikolic, I. \& Borovic, S. (1996). Višekriterijumska optimizacija, metode primene u logistici, softver, Centar vojnih škola Vojske Jugoslavije, Beograd.

[24] Pavlovic, M., Cerenak, A., Pavlovic, V., Rozman, C., Pazek, K. \& Bohanec, M. (2011). Development of DEX-HOP multi-attribute decision model for preliminary hop hybrids assessment, Computers and Electronics in Agriculture, 75(1), 181-189.

[25] Petrovic, I., Gordic, M. \& Kankaras, M. (2018). Fuzzy - AHP pristup u vrednovanju kriterijuma za izbor raketnog Sistema za protivvazduhoplovna dejstva. Vojno delo, 70 (2), 298-308.

[26] Petrovic, I. \& Kankaras, . (2018), DEMATEL-AHP multi-criteria decision making model for the selection and evaluation of criteria for selecting an aircraft for the protection of air traffic, Decision Making: Applications in Management and Engineering, 1(2), 93-110 DOI: 10.31181/dmame1802091P.

[27] Petrovic, I. \& Kankaras, . (2020), A Hybridized IT2FS-DEMATEL-AHP-TOPSIS Multi-Criteria Decision Making Approach: Case Study of Selection and Evaluation of Criteria for Determination of Air Traffic Control Radar Position, Decision Making: Applications in Management and Engineering, 3(1), 146-164, DOI: 10.31181/dmame200301P.

[28] Radovanovic, M., Randjelovic, A. \& Jokic, Z., (2020). Application of hybrid model fuzzy ahp - vikor in selection of the most efficient procedure for rectification of the optical sight of the longrange rifle, Decision Making: Applications in Management and Engineering 3(2), 131-148, DOI:10.31181/dmame2003131r

[29] Radovanovic, S., Delibasic, B., Suknovic, M. \& Matovic, D. (2019). Where will the next ski injury occur? A system for visual and predictive analytics of ski injuries. Operational Research, 19, 973-992 DOI:10.1007/s12351-018-00449-x

[30] Richard, W. C., Matthew, E. B. \& Heather, M. B. (2014). Multi-criteria Decision Analysis Approach to Site Suitability of U.S. Department of Defense Humanitarian Assistance Projects, Humanitarian Technology: Science, Systems and Global Impact 2014, Procedia Engineering, 78, 59 - 63. DOI: 10.1016/j.proeng.2014.07.039 
[31] Rozman, Č., Maksimovic, A., Puska, A., Grgic, Z., Pazek, K., Prevolsek, B. \& Cejvanovic, F., (2017). The Use of Multi Criteria Models for Decision Support System in Fruit Production. Erwerbs-Obstbau. 59(3), 235-243. DOI:10.1007/s10341-017-0320-3

[32] Saracoglu, B. O. (2016). A Qualitative Multi-Attribute Model for the Selection of the Private Hydropower Plant Investments in Turkey: By foundation of the search results clustering engine (Carrot2), hydropower plant clustering, DEXi and DEXiTree, Journal of Industrial Engineering and Management, 9(1), 152-178. DOI: $10.3926 / \mathrm{jiem} .1142$

[33] Wibowo, A. S., Permanasari, A. E., \& Fauziati, S. (2016). Combat aircraft effectiveness assessment using hybrid multi-criteria decision making methodology. In 2016 2nd International Conference on Science and Technology-Computer (ICST) (pp. 112-117). IEEE. Retrieved from ww.xplore.ieee.org/abstract/document/7877358/authors\#authors (accessed 20.08.2020.)

[34] Woodford, Sh. (2019). Historians and the Early Era of U.S. Army Operations Research, Retrieved from www.dupuyinstitute.org/blog/tag/operations-research-office-oro/ (accessed 04.03.2020).

[35] Zupanic, K. (2017). Primjena DEX metode u donošenju poslovnih odluka (Diplomski rad). Retrieved from https://urn.nsk.hr/urn:nbn:hr:211:385087

Received: 2020-11-05

Revisions requested: $2020-12-11$

Revised: 2021-02-07 (2 revisions)

Accepted: 2021-02-10
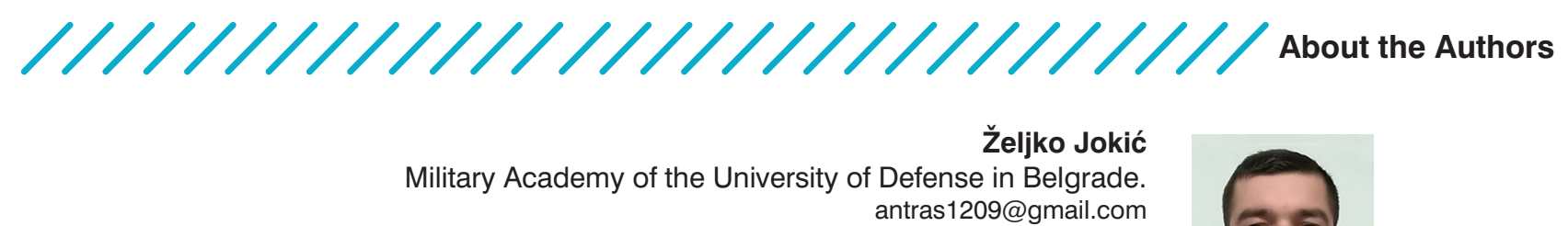
antras1209@gmail.com

Željko Jokić, MSc, is a teaching assistant at the Department of Arms and Equipment of the Land Army at the Military Academy of the University of Defense in Belgrade.

His research interests are related to defense management, armaments and shooting, multi-criteria decision making. The author has published more than 10 papers in national and international conference proceedings

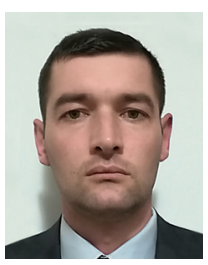

Boris Delibašić University of Belgrade, Faculty of Organizational Sciences, Serbia boris.delibasic@fon.bg.ac.rs

Boris Delibašić is a full professor at the University of Belgrade - Faculty of Organizational Sciences, Republic of Serbia. His research interests lie in data science, machine learning, business intelligence, multicriteria decision analysis, and decision support systems. He is a coordinator of the EWG-DSS. He was a guest lecturer on the Friedrich Schiller Uniersity of Jena, Germany, 2006 - 2011. He was awarded a Fulbright Visiting

Scholar Grant in 2011. He has been principal investigator on projects from several research agencies (Swiss National Science Foundation, German academic exchange service, Office for Naval Research, Serbian Ministry of Science).

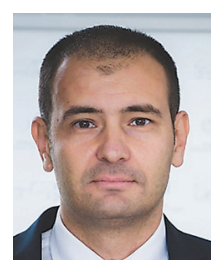

Aca Ranđelović Military Academy of the University of Defense in Belgrade. aca.r.0860.ar@gmail.com

Assistant Professor Aca Randjelovic, PhD, works at the Military Academy of the University of Defense in Belgrade, Serbia. He has published a large number of research papers in scientific journals at domestic and international conferences. His main research field is shooting theory.

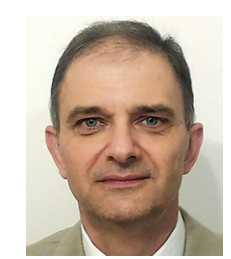

